- if the holder of the certifying certificate revoked their key promptly upon finding out their system or key was compromised

- which of the two innocent parties (relying party and holder) was in the better position to protect themselves from damage at the hands of an impostor.

Whether electronic signatures will ever be used widely is a matter that only the passing of time will determine. The main issue surrounding electronic signatures relates to the ease by which a signature can be misused. This article seeks to show that there are many ways in which the use of an electronic signature can be challenged, although it is doubtful that there will be large numbers of disputes which focus on the sole issue of whether an electronic communication was signed by an unauthorised electronic signature. (c)
(C) Stephen Mason, 2002

Stephen Mason is a barrister and Chairman of Pario Communications Limited. He specialises in e-risks, e-business, data protection and interception of communications.

stephenmason@pariocommunications.co.uk

This paper was written to accompany a lecture given to a joint meeting of the Society for Advanced Legal Studies and British Computer Society Internet Specialist Group on 15 November 2001 in Senate Room, Senate House, University of London, chaired by David Spinks, Director Information Assurance, EDS.

This paper was first published in two parts in The Computer Law and Security Report, Part I May/June 2002, Volume 18, Issue 3, 175 180, Part II July/August, Volume 18, Issue 4, 241 - 248.

Readers may download a copy of this paper from the web site, which contains the full references.

\title{
The law as Janus: children, crime and care
}

\author{
by Peter Harris
}

\begin{abstract}
My inspiration for the choice of the subject of this article is the Michael Sieff Foundation conference which took place in September 2001 on "The Needs of Offending Children". The focus of that conference was the forensic dichotomy that is represented by the Civil and Criminal Justice Systems when the State intervenes in the lives of children in respect of events which require a judicial decision. This lead naturally to the title I have given to this article since the Roman god Janus is always depicted as a head with two faces looking in opposite directions.
\end{abstract}

$\mathrm{T}$ he media treat children generally as either young villains or victims, and as if young offenders fall exclusively into the former category. However those who deal with them professionally know that children with unmet welfare needs and children who commit crime are not disparate populations. The two categories certainly overlap, and the latter category is pretty much a sub-set of the former, which is defined by section 17 (10) of the Children Act 1989 in respect of a child who:

“.... is unlikely to achieve or maintain, or have the opportunity of achieving or maintaining, a reasonable standard of health or development without the provision ... of services by a local authority ... his health and development is likely to be significantly impaired without the provision of such services ... [or] .... he is disabled, ..”.

Disability includes being blind, deaf, dumb or suffering from mental disorder of any kind. Development includes physical, intellectual, emotional, social or behavioural development, and health means physical or mental health. (The relevance of these definitions I shall refer to in greater detail in due course).

My starting point, however, is a quotation from the Roman poet Juvenal which was used by Lord Hewart, the Lord Chief Justice in 1931 when delivering the second Clarke Hall lecture on young offenders - or as he called 
them in the jargon of the times "juvenile delinquents". He began with Juvenal's maxim "maxima debetur puero reverentia" - which can be translated as; "The highest respect is owed to the young". I commend, if you will allow me, that maxim to you. Lord Hewart referred in his lecture to the situation of young offenders 100 years before, ie in the 1830 s , citing as his source the Prison Register of Stafford Prison. The register contained the following records -

\begin{tabular}{|c|c|c|c|c|}
\hline Year & Name & Age & Offence & Transportation \\
\hline 1837 & Matilda Seymour & $10 \mathrm{yrs}$ & $\begin{array}{l}\text { Theft of a shawl } \\
\text { and petticoat }\end{array}$ & 7 yrs \\
\hline \multirow[t]{2}{*}{1843} & Wm Carless & 16 & Theft of 1 spade & $10 \mathrm{yrs}$ \\
\hline & Wm Ashmole & 14 & $\begin{array}{l}\text { Theft of } 1 \text { book } \\
\text { the property of } \\
\text { the Guardians of } \\
\text { the Poor }\end{array}$ & $7 \mathrm{yrs}$ \\
\hline \multirow{3}{*}{1834} & Geo Saxon & 12 & Theft of gold watch & 7 yrs \\
\hline & Wm Bigden & 14 & Theft of 1 silk h'chief & 7 yrs \\
\hline & Thos Tow & 10 & Theft of 1 ass & 7 yrs \\
\hline \multirow[t]{2}{*}{1835} & Geo Bold & 15 & Theft of 1 pce mutton & $7 \mathrm{yrs}$ \\
\hline & Thos Bell & 11 & Theft of 2 silk h'chiefs & $7 \mathrm{yrs}$ \\
\hline
\end{tabular}

As the Lord Chief Justice remarked - "Little if any distinction seems to have been drawn between the adult offender, the adolescent and the juvenile. They were all dangerous, all a nuisance, all fit for punishment ....". We may be aghast at the punishments our forebears meted out for trivial offences, but that last comment is reflected in what we hear daily from the media about young offenders.

Matters did begin to advance from the beginning of the 20th Century, the first major change being brought about by the Children Act 1908. This introduced separate courts for the trial of children - the Juvenile Courts - which had both civil and criminal jurisdiction. The "delinquent" child, that is one who had been convicted of a criminal offence, was not treated very differently from a child in need of care, since both were committed to the same institutions. Institutional care was the norm. There was thus equality of treatment since those who experienced State intervention in order to address welfare needs, and those whom the State was punishing for misdeeds, were disposed of in a similar way. There was another characteristic which they had in common overwhelmingly they were the children of poor parents. Indeed, prior to the Children Act 1948 most children were taken into care as a consequence of destitution under the Poor Law, whose latest emanation was the Poor Law Act 1930, section 15(1) of which required orphan and other destitute children to be "set to work".

In 1944, according to the Ministry of Health's Memorandum The Break Up of the Poor Law and the Care of Children and Old People, some 27,000 children were in the care of the poor law authorities, only about $15 \%$ of whom were fostered.

It is interesting to note that though transportation had been abolished as a sentence when the Colonies had acquired sufficient independence to object to being used as a dump for British criminals, it continued in effect for children. For example, between 1850 and 1967 one children's charity alone, the Fairbridge Society, exported in excess of 100,000 children between the ages of three and 17 to Commonwealth countries. Children were apparently told that their parents were dead, though this was not necessarily the case. The Society's aim was to populate the Colonies with "pure white stock", and the concept of the children's human rights not well developed.

\section{CHILDREN AND YOUNG PERSONS ACT 1933}

Having made a major step forward in creating a special court for children in the form of the Juvenile Courts, the next fundamental step in the consideration of the welfare of the child in criminal proceedings was the Children and Young Persons Act 1933. Section 44(1) of that Act, which is still extant and operative, requires that:

$$
\begin{aligned}
& \text { Every court in dealing with a child or young person who is } \\
& \text { brought before it either as being in need of care and } \\
& \text { protection, or as an offender or otherwise, shall have regard to } \\
& \text { the welfare of the child or young person." }
\end{aligned}
$$

This firmly established in statute recognition of the fact that the welfare needs of young offenders must be considered by the criminal courts. In more recent times those needs have not been to the forefront of the minds of the media, the prison service or politicians - at least not until very recently, and then in a somewhat equivocal fashion. Part III of the 1933 Act gave the court the power to commit a child found guilty of an offence, as well as a child who had been neglected or ill treated to the care of a fit person, which included a local authority. The Home Office, whose responsibilities at that time included children, expressed the view that it "was often an accident" whether a child came before a court as a delinquent or as a neglected child. This rather enlightened view, however, underpinned a policy of not separating the "deprived" from the "depraved" on the ground that to do so would be "inconsistent with the spirit and intention of the" legislation. The welfare needs of any accommodated child, it appears, did not demand more than shelter, food and clothing.

The London County Council Remand Homes Inquiry of 1945 (1945 Cmd. 6594) was the result of the publicity given to the complaints of a Metropolitan Stipendiary Magistrate, John Watson, about a seven year old girl found to be in need of care and protection being admitted to Marlesford Lodge Remand Home. His complaint was that a child of this age should not be accommodated with 43 adolescent girls who were prostitutes or had criminal convictions. The public concern that had been aroused by such matters, was further fuelled by the death of a 12 year old boy, Dennis O'Neill, while in the care of Newport County Borough Council. He had been starved and beaten by his foster parents. These comcerns led to the setting up 
of the Curtis Committee, (Report of the Care of Children Committee (1946) Cmd. 6922). The recommendations of the Curtis Committee about meeting the welfare needs of children in care were implemented in the Children Act 1948.

The Children Act 1948 made further changes to the protection of children and the child welfare regime., but it did not affect the treatment of young offenders. J.E. Cavanagh observed, in his book Juvenile Courts, The Child and The Law:-

"The practical difficulty in submitting child offenders to the criminal justice jurisdiction was ..... that the extent of a child's social need and the gravity of the offence were not necessarily in proportion to each other."

and also that:-

".... the procedure for dealing with non-criminal cases is in many ways similar to that for trial on a criminal charge, though no question of criminal responsibility is involved."

Regrettably the similarity in procedure tended, of course, to criminalise the civil process, rather than draw the criminal process into a more welfare orientated mode.

\section{DEVELOPMENTS IN THE 1960s}

In the 1960s the Ingleby Committee (Report of the Committee on Children and Young Persons (1960) Cmnd. 119) reporting on the issues concerning juvenile criminal justice, amongst other things, recommended that a child under the age of 12 years should not be subjected to criminal trial for alleged offences. The Committee recommended instead that such a child should be dealt with as one in need of care and protection. The Ingleby Committee also recommended that the concept of doli incapax should be abolished, a step that was not taken until 1998. The age of criminal responsibility, of course, is still 10, a lower age than that in most of our European neighbours.

In the early 1960s the Labour Government decided that it should address afresh the question of the way in which the welfare of the child offender should be approached. They decided that it was appropriate to regard the delinquent child as a child whose welfare was at risk. In 1965 they published their White Paper The Child, the Family and the Young Offender (1965) Cmnd. 2742. They proposed that, in lieu of a court, cases of delinquency, care, protection and control should be heard by a "family council". This would be a non-judicial body, though when a child had been accused of a criminal offence the child could elect to have the issue of guilt decided by a court. This was a controversial proposal, and no legislation followed in England and Wales, though the concept was adopted in Scotland in the form of the Children's Hearing system.

However, in 1968 there was a further White Paper, Children in Trouble (1968) Cmnd. 3601, which set out the policy that was followed in the Children and Young
Person's Act 1969. The 1969 Act preserved the Juvenile Courts, but Part 1 gave the court the power to make a care order in respect of a young offender, enabling the court to give priority to his or her welfare needs. Part 1 of the 1969 Act has never been brought into force, and the dichotomy of procedures, civil and criminal, has persisted to the present day.

The philosophical argument for preserving the dichotomy was that the "welfare" approach tends towards an administrative rather than a forensic solution. To adopt the "welfare" approach would result in the dilution of children's rights to the point of their being washed away. This is a criticism that is levelled at the Scot's system of Children's Hearings. This view is based upon the importance of protecting the right of a child to a trial of the issue which brings the child before the court, namely whether an offence has been committed by the child. Since it is offending behaviour which confers on the State the right to intervene in the life of the child, the fact of offending behaviour should be established with the full rigour of the criminal process, including a finding of guilt beyond reasonable doubt. It is only when that fact has been properly found, with the exercise by the child of all the rights which any accused may deploy, that the court ought to decide upon disposal. In short, this argument is in favour of an offence orientated approach rather than a child centred one.

\section{THE BULGER CASE}

Hand in hand with this philosophy goes the concept of the child taking responsibility for his or her actions. The child, it is argued, must be held responsible for what it does - at least from the age of 10 with regard to criminal offences - and it follows that punishment must be meted out to mark Society's disapproval of offending behaviour. Put perhaps a little crudely, young criminals must be made to face up to their behaviour, and it is for their good, and the good of Society, that a "short sharp shock" should be administered to get them back on the straight and narrow path of good behaviour. Certainly little concession was made to the tender ages of the two defendants in the infamous Bulger case who were tried in the Crown Court at Preston. The courtroom in which the puisne judge sits is a masterpiece of Edwardian grandeur, with the judge on the bench looming over the amphitheatre of the court.

While the surroundings are certainly impressive - and much loved by counsel - they can only have added to the incomprehension of the defendants. Venables and Thompson were, of course, protected after sentence by the invocation of the inherent jurisdiction of the High Court in the making of an injunction in rem to prevent the identification of their places of detention. Nevertheless, the European Court of Human Rights held that their trial was in breach of Article 6 of the European Convention on Human Rights, because subjecting them as children to the form of proceedings in the Crown Court denied them the 
right to a fair trial. In the words of the European Court of Human Rights:

"It is essential that a child charged with an offence should be dealt with in a manner which took full account of his age, level of maturity and intellectual and emotional capacities, and that steps are taken to promote his ability to understand and participate in the proceedings."

Lord Justice Auld in his report on the criminal justice system has recommended that there be a separate youth court at the equivalent of Crown Court level to try children for serious offences, and meanwhile the Lord Chief Justice's Practice Direction on the trial of young defendants in the Crown Court has gone some way to meeting the criticisms made by the European Court of Human Rights.

\section{COMPARING BULGER WITH TWO 19TH CENTURY CASES}

I suggest that it is instructive to compare the case of Thompson and Venables, and the way in which these two children were dealt with by the court, the media and later by the Home Secretary, with two 19th century cases. Our Victorian ancestors it appears from at least two very similar cases, one in Liverpool the other in Stockport, took a very different approach. It is also worth noting that the Press of the day also dealt with these cases in a sober and much more responsible manner than tabloid editors did in the last decade of the 20th century. In the Liverpool case, in 1855, a little boy aged 9 attacked a little boy of 7 . He hit him on the head with a brick - twice. The attacker then called a companion of the same age to help throw the 7 year old into the Liverpool - Leeds canal. Both boys then watched the 7 year old's body disappear under the water. These boys were tried for murder, the age of criminal responsibility then being 8 years of age. They were convicted of manslaughter and sentenced to 12 months imprisonment. The judge directed that during their term of imprisonment the boys were to be given the assistance and guidance of the chaplain and a schoolmaster to instruct them.

The second case, which took place in 1872 in Stockport, concerned two boys aged 10 and 11 respectively. They assaulted a 3 year old boy and held him face down in a stream in Great Underhill - an area which housed the local mill workers. They were tried, and convicted, on an indictment for murder. However, they were sentenced to imprisonment, but to be committed to the care of a doctor who ran a children's home in Macclesfield. The press was surprisingly sympathetic to the two young offenders, reporting on the deprived backgrounds from which they came. The boys were released from their confinement at the age of about 16 or 17 , one becoming apprenticed to a carpenter and the other emigrating to Australia.

To return to more modern - and perhaps in some respects less compassionate - times, various regimes were tried to deter young offenders from re-offending, without great success. It was in the Criminal Justice Act 1991 that the "just deserts" policy of the then Conservative administration was given effect. This was a policy whose primary purpose was to deter young criminals by punishing them in a strict regime to bring home to them their responsibilities, in order to turn them into good citizens. The policy of getting tough with juveniles in order to combat the rising tide of juvenile crime was perpetuated in the Criminal Justice and Public Order Act 1994. The "boot camp" regime introduced by the secure detention order, imported from the United States, was successful at least in turning out very fit young criminals, but it did not reduce recidivism. Welfare needs was not a term which was heard at the time in respect of young offenders, and addressing the welfare needs of young offenders was not considered to be an essential element in helping young offenders to address their offending behaviour.

\section{DUTIES OF LOCAL AUTHORITIES TO CHILDREN IN NEED}

At this point I want to consider the duties of local authorities to children in need. I have earlier referred to section 17(10) of the Children Act 1989 which places upon each local authority a duty to identify children in need in their area. Local authorities must provide appropriate services to children in need, as defined in section $17(10)$ by virtue of section $17(1)$ and section 22(3)(b). If a child is considered to be at risk of significant harm the local authority must decide whether it should take proceedings for a care or supervision order under section 31 of the 1989 Act. It will call a case conference of representatives of all the relevant agencies - eg police, education, health and social services - to share information on the child's circumstances. If on the basis of that information the local authority is satisfied that the criteria in section 31 of the 1989 Act are fulfilled it will usually institute care proceedings. The criteria are that the child is suffering, or is likely to suffer, significant harm by reason of not being given the care that it would be reasonable to expect a parent to give to a child, or that the child is beyond parental control. Harm is defined as illtreatment or the impairment of health or development, and development means physical, intellectual, emotional, social or behavioural development, health means physical or mental health and ill-treatment includes sexual abuse and forms of ill-treatment which are not physical.

The circumstances of young offenders, particularly persistent young offenders, will frequently meet one or both the criteria contained in section 31 . Young offenders in custody, whether on remand or undergoing a custodial sentence, will often also be in circumstances where the criterion of significant harm is fulfilled, because of deficits in the care they are afforded by the Prison Service. However, the Children Act 1989 is not applied by local authorities in respect of a child in custody (see R (on the 
application of the Howard League for Penal Reform) $\mathrm{v}$ Secretaries of State for the Home Department and for the Department of Health [2002] EWHC 2497 (Admin)) unless remanded under section 25 of the Children Act to local authority secure accommodation. Nor does the Prison Department have any duty under the Children Act towards young offenders in its care. A parent who locked a child in a small room containing a lavatory for 20 hours a day, and made the child eat all its meals there, would certainly be regarded as not providing the care which a reasonable parent would give a child, and the child would undoubtedly be at risk of significant harm within the definition of harm in Section 31 of the Children Act.

Many young offenders in custody are subjected to conditions of this sort. In 1991 and 1995 respectively two research studies were published by Boswell of the University of East Anglia. He was particularly concerned with child offenders who had committed serious offences - eg murder, arson, rape etc - which had been dealt with by custodial sentences under section 53 of the Children and Young Persons Act 1933. He found that 91\% of these young offenders had experienced childhood trauma by abuse, loss (such as bereavement) or both. While treatment for children may be available in the child care system, it is hardly ever available in the prison system. Boswell found that where it is available it is usually provided because of the personal interest taken by individual prison or probation officers in a particular institution. There is no juvenile equivalent of Grendon Underwood where adult prisoners participate in very successful therapeutic and rehabilitative programmes.

The present Administration proposed a new system of Criminal Youth Justice in its 1997 White Paper No More Excuses - A New Approach to Tackling Youth Crime in England and Wales (Cm. 3809). It gave effect to those proposals in the Crime and Disorder Act 1998 and the Youth Justice and Criminal Evidence Act 1999. Its aim is to place greater emphasis on rehabilitation of offenders and prevention of offending. It does this through the work of the Youth Justice Board which was created by section 41 of the 1998 Act. The Board is responsible for advising the Home Secretary, setting, monitoring and inspecting standards for punishment in the community, identifying and disseminating good practice and for commissioning and purchasing places in the "secure estate" (ie young offender institutions) from the Prison Department It monitors the work in the community of the Youth Offending Teams (YOTS).

These teams are provided by local authorities under sections 38 and 39 of the Crime and Disorder Act 1998. They are made up of members from the police, probation, health, education and social services, as well as from Drugs Agencies, Mentors, Voluntary Agencies and Youth Services. 154 of these teams were set up by April 2002. Their aim is to help young offenders change their behaviour, but they also administer punishment in the community which includes the Intensive Supervision and Surveillance Programmes concerned with the $3 \%$ of young offenders who commit 25\% of offences. The YOTS retain responsibility for young offenders who are serving custodial sentences, though the relationship between the YOTS and the Prison Officers is not always an easy one.

\section{INITIATIVES IN DEALING WITH YOUNG OFFENDERS}

The Government has taken a number of initiatives in dealing with young offenders, with a strong emphasis on crime prevention, and some of them do include measures to remedy deficits in the circumstances of young offenders. New orders have been introduced under the 1998 Act, such as the Parenting Order (section 8), which requires parents to attend for advice and training sessions, the Reparation Order (section 67) and Curfew Orders (section 14) enforced by electronic tagging. None of these, however, save perhaps the Parenting Order, seek to address the welfare needs of young offenders. Nor does the power, taken in section 130 of the Criminal Justice and Police Act 2001, to remand in custody for a wider range of offences young offenders who are alleged to have committed offences while on bail.

Of course, these are all measures directed towards protecting the citizen from criminal activity, and that is a necessary and laudable purpose. No one would sensibly disagree with appropriate measures to reduce crime, especially street crime and offences of violence. Why then, as the tabloid press might ask, the concern with welfare needs of young thugs? The answer lies in the research into the characteristics and backgrounds of young offenders. The risk factors for offending are well-established - low educational achievement, bullying at home and at school, truanting, poor and harsh parenting, poverty and poor housing, substance abuse and the high availability of drugs and poor mental health. A high proportion of young offenders have some form of mental disorder stemming from such causes as physical, emotional and sexual abuse, physical disability such as deafness and speech disorders, drug and alcohol abuse as well as learning difficulty. These in turn give rise to severe literacy problems and difficulties in communication. If help is not given in overcoming these severe disadvantages a child will face enormous obstacles to gaining a reasonable education and acquiring life and work skills to equip him or her to be a self supporting truly autonomous adult, and in due course a successful parent.

The Howard League for Penal Reform has produced two reports on Children in Prison. The first concerned provision and practice at Lancaster Farms situated near Lancaster, The second report was on Castington in Northumbria. These are two of the thirteen male young offender institutions in England and Wales. The reports are measured in tone and give due recognition to the work of the prison staff. They describe, however, a number of areas of concern about young offender institutions generally and 
their failure in a number of respects to meet the needs of the young people incarcerated. These include a lack of screening of staff for suitability to work with children and a lack of specialist training (this latter point echoes a criticism made by the Curtis Committee some 55 years earlier about staff in children's homes). Sir David Ramsbottom, formerly HM Chief Inspector of Prisons, took a very close interest in young offender institutions and also expressed his concerns about the lack of selection and training for prison officers working in these establishments.

The Howard League Reports also noted the high level of violence in young offender institutions and that bullying was widespread and insidious, that staffing levels were inadequate, particularly at night time, and that there was poor preparation and education for release. The latter deficit is compounded by the effect of the Prison Rules which apply to young offenders in the same way that they apply to adult prisoners. Those rules have the effect of preventing release on temporary licence (that is to be allowed out of prison for a short period) if a prisoner has committed certain offences, which include bail offences. It is not uncommon for young offenders not to come to court on every occasion when they should do so, and as a consequence breach their bail conditions. If given a custodial sentence, that is a detention and training order under the Crime and Disorder Act 1998, the rules will later preclude them being released on temporary licence to complete, for example, an NVQ or to attend a job interview pending release.

The winds of tabloid journalism sometimes blow hard and politicians bend before them. For example, we read not long ago of the Home Secretary's response to the pictures of an 11 year old multiple offender trying to kick in a shop window in Bristol while on bail. His response is to promise greater powers for magistrates to remand 12 to 16 year olds in secure accommodation, and to devise an "... expansion of the operation of care orders and the way in which protective custody can be contemplated when the family has broken down, the community has not been able to intervene and professional service have not been able to stop continuing misbehaviour.”

\section{USE OF CARE ORDERS}

The wheel seems to turn and take us back to the idea that placing a child in care is an appropriate response to criminal activity. While I, for one, do not regard a care order as an inappropriate measure to deal with a child who is clearly beyond parental control, or is at risk of harm (as defined in the section 31 of the Children Act 1989) by reason of lack of parental care, I am uneasy at the concept of using care orders to take young offenders off the streets. My unease stems from the doubt that the needs of the child, which are not well served in local authority care as a general rule, will receive even less attention if the child is in care as a result of criminal offences. We must take great care not to try to solve one problem by recreating the abuse of children that our predecessors perpetuated in the first half of the last century in children's homes and institutions like the London County Council Remand Homes. In just over the last 12 months there have been three deaths by suicide in young offender institutions. The latest to die was Joseph Scholes who hanged himself in his cell at Stoke Heath on 24 March 2002 at the age of 16. He had a history of sexual abuse by a relative, a fight over residence after his parents' acrimonious divorce, psychiatric problems and treatment. He had made several previous serious suicide attempts and had severely harmed himself by cutting. He was in custody because he had pleaded guilty to robbery as part of a group of youths from the children's home in which he was living in voluntary care. His family and medical history, and the previous suicide attempts, apparently did not give the prison authorities cause to allocate sufficient priority to addressing his pressing needs to prevent this tragic death.

\section{RECENT ADVANCES}

All is by no means gloom, and it would be wrong to overlook the advances that have been made by the Youth Justice Board, the Youth Offending Teams and the Prison Service in the last three years. The Youth Justice Board has sought to ensure that the prison staff in the young offender institutions liaise with their local Area Child Protection Committees, and that prison staff are trained in child protection issues. Steps have been taken to improve education for young offenders, for example by a national strategy for literacy and numeracy in the youth justice system. A greater emphasis has been placed on health issues, particularly mental health, in the Youth Offending Teams. The Parenting Orders under the Crime and Disorder Act 1998 are being increasingly used, and have on the whole been successful in improving child-parent relationships. More attention is being paid to housing by providing better support for children living outside the family home, and by remand fostering. The improvements in addressing the needs of young offenders in the community and in custody is encouraging, but a great deal remains to be done.

There is one measure which could improve the situation by identifying the difficulties in a child offender's circumstances at an early stage, and which I hope will be taken up. It has attracted the support of the President of the Family Division, and it might be possible to add it to the Adoption and Children Bill currently before Parliament. The measure is designed to avoid the problems that inevitably arise if a criminal court is given the power to make a care order as a means of safeguarding a child's welfare. The criminal process is not suited to enabling a court to make a decision of this nature. The criminal process is concerned with the investigation of a single event or a series of linked events, that is whether a crime has been committed by the accused. It is a snapshot of activity with respect to an individual. The question whether a 
child's circumstances require him to be removed from the care of his family to the care of a local authority to safeguard his welfare calls for an investigation into events over the course of time, and an inquiry into family circumstances and history. This is not a matter that naturally falls within the purpose of a criminal court. If it had to carry out such an exercise it would have to turn itself into a different sort of tribunal with a different sort of process. In other words it would have to become a civil court conducting a civil procedure.

The alternative is to provide the Youth Court with power to consider when a child is charged with a crime whether the case might more appropriately be handled by the Family Proceedings Court. This could be effected by extending a provision on the lines of section 37 of the Children Act 1989 to the Youth Court. That section allows a court dealing with family proceedings where a question arises as to the welfare of a child to direct the appropriate local authority to undertake an investigation into the child's circumstances. Under section 37 the local authority is then under a duty to report to the court within 8 weeks whether it intends to apply for a care or supervision order in respect of the child, and if it does not to explain why. On the making of a section 37 direction the Family Proceedings Court appoints a Children's Guardian to represent the child's interests, and it would seem appropriate to confer such a power on the Youth Court. The basis upon which a Youth Court would make such a direction would be information provided by the Youth Offending Team. The YOTs have a duty to act to prevent offending, and if a care order might be more effective in this regard, then it would be proper for the YOT to make a recommendation to the Youth Court. If the local authority reported that it would institute proceedings for a care or supervision order, the Youth Court would have to have power also to transfer the matter to the Family Proceedings Court, and to adjourn the criminal proceedings sine die, or allow the prosecution to withdraw the charges and dismiss them. The child's circumstances would then be dealt with as a welfare matter by way of care proceedings in the Family Proceedings Court.

While this procedure may seem rather cumbersome it has the advantage of separating civil and criminal disposals, and of avoiding children being placed in the care of a local authority inappropriately. It also provides a better safeguard for the child's welfare since the Family Proceedings Court dealing with the child will have this as its paramount concern by virtue of section 1 of the Children Act 1989. That section requires that when a court determines any question with respect to the upbringing of a child it shall have the child's welfare as its paramount consideration. The Youth Court on the other hand has to decide whether the child is guilty of an offence, and if so what is the most appropriate punishment. Although, by virtue of section 44(1) of the Children and Young Persons Act 1933, it must have regard to the child's welfare, this is not its paramount concern. Criminal procedure does not allow for the sort of investigation and hearing necessary for a sound decision to be made on whether the criteria for making a care order have been satisfied. If a care order is made into a species of criminal disposal it would be made as a punishment and not to prevent the child from suffering significant harm.

I hope that this brief exposition of the way in which the law has dealt with the welfare of children who are offenders on the one hand, and children in need of protection on the other, has sufficiently shown the way in which it has tried to face in two directions, all too often simultaneously to the detriment of the child, and with a lack of concern about the child's needs. With regard to the child brought before the court in need of care and protection, the Children Act 1989 has done much to ensure that the welfare needs of the child receive attention. The same cannot be said for c child subject to criminal proceedings. I am confident that if more attention is paid to the needs of child offenders, as seems to be the general intention of the Youth Justice Board, there will be fewer of them, and fewer child recidivists.

I began this piece with a quotation from an address by Lord Chief Justice Hewart. I will end it with another quotation from the same source. He said in respect to young offenders :

"The State may sometimes be compelled to be stern. It must not be cruel. It cannot afford to be indifferent".

\section{Peter Harris}

Barrister; formerly the Official Solicitor to the Supreme Court

This article is taken from a lecture of the same title given by the author at the Institute of Advanced Legal Studies. 